IBT Journal of Business Studies

Volume 14(2), 158-173, 2018

\title{
Impact of Privatisation On Financial Performance and Efficiency of State Owned Enterprises
}

\author{
Bilal Ahmed \\ Sadaf Alam ${ }^{2}$
}

\begin{abstract}
This study designed for inspecting the potential effect of privatization on the financial performance and efficiency of the Cement Sector (Kohat Cement Company and Dandot Cement Company), Oil and Gas Sector (PPL and NRL) and Service Sector (PTCL and KESC). This research is an effort to contribute in the discussion on how privatization of state-owned enterprises may impact on the financial performance and efficiency of these enterprises. The data were obtained from the State Bank library of Pakistan, Official websites of selected companies, Security and Exchange Commission of Pakistan and Karachi Stock Exchange of five years pre and five years' post-privatization. Moreover, Paired t-test applied for determining and comparing the significant differences among companies' financial performances and their efficiency levels, under before and after privatization periods. The findings revealed that privatization has an insignificant impact on Cement Sector, as well as, on Service Sector. However, there is a significant impact of privatization on Oil and Gas Sector documented in this research. Furthermore, instead of privatizing companies, the government of Pakistan should accept the skills of individual persons and understand that they can resolve issues more brilliantly as compared to the third party.
\end{abstract}

Keywords: Privatization, Financial performance, Efficiency, State-owned enterprises, Paired t-test

1- Bahria University Karachi Campus, bilalahmed.riceintl@gmail.com

2- Bahria University Karachi Campus sadafalam.bukc@bahria.edu.pk 


\section{INTRODUCTION}

\section{Background}

Since 1945, there are many countries of the world that tried to practice the state-owned enterprises (SOEs) to attain their social objectives, as well as economic objectives. In both developed and under developing countries, privatization occurs as a key phenomenon. Most of the underdeveloped countries are more dependent on SOEs as compared to industrial economies. Therefore, they tried to attain anticipated balance or switch the weak ideologically undesirable private sector.

In the expansion of an economy, efficiency level of the economy, as well as social infrastructure, are usually considered critical factors. The idea of privatization occurred, when empirical studies show that SOEs are comparatively ineffective and drain on the public treasury. Thus, economy functioned by the private sectors, where operators are well known due to their efficiency level and competitive soul, to change and be worldly embraced (Bdour et al. 2007).

In the late eighties, the process of privatization took place in Pakistan. Moreover, its mission statement was clearly mentioned as - "Privatization is envisaged to foster competition, ensuring greater capital investment, competitiveness, and modernization, resulting in enhancement of employment and provision of improved quality of products and services to the consumers and reduction in the fiscal burden" (Hakro and Akram, 2009).

Generally, it is believed that performance of an organization improved by the privatization. Megginson and Netter (2001) observed that other than profit maximization, the government also fulfil other objectives including, social welfare maximization and political motives. Financial performance can be affected by the SOEs' contradictory roles. Thus, privatization considers a feasible alternative measure to enhance firm's performance level. Theoretically, it is anticipated that there is the relatively greater performance of firms as compared to SOEs. Moreover, operating efficiency level of privatized firms improves by the privatization (Megginson et al. 1998). Furthermore, there is a number of empirical evidence exists to show the improvement in the financial performance under postprivatization period. While having the performance level of 61 companies in before and after privatization period, Megginson et al. (1998) explore that in post-privatization operating efficiency, investment spending, real sales and profit increased.

The privatization process of SOEs in considers compound as well as the complex issue. It utilizes both kind of material and non-material measures, as well resultant far-reaching economies, political, and social repercussions. Particularly, the instant privatization effect of SOEs is financial position as well as financial performance of privatized institutions. Moreover, it depends on the process and rationale of privatization. Therefore, via acquiring the privatized firm's performance level, future policies of privatization should be taken by considering what has been attaining with respect to previous privatized firms. The aim of this study to focus on privatization in Pakistan having 06 listed companies of Karachi Stock Exchange, by giving specific attention to the financial performance and efficiency level of the State-owned enterprise. Therefore, the study intends to check whether there is any type of gains experienced in post-privatization of SOEs in Pakistan, in terms of financial performance and efficiency level.

\section{Research objectives}

The main objective of the study is to observe the Pre and Post impact of Privatization on Financial Performance and Efficiency of the State-Owned Enterprises (SOE).

1 To observe the impact of pre and post Privatization on Profitability of State-Owned Enterprises in Pakistan 
IBT Journal of Business Studies

2 To observe the impact of pre and post Privatization on Liquidity of State-Owned Enterprises in Pakistan

3 To observe the impact of pre and post Privatization on Operating Efficiency of State-Owned Enterprises in Pakistan

4 To observe the impact of pre and post Privatization on Leverage of State-Owned Enterprises in Pakistan

5 To observe the impact of pre and post Privatization on Dividends Payout of State-Owned Enterprises in Pakistan

\section{LITERATURE REVIEW}

Hakro and Akram (2009) examined the performance of pre and post-privatization by taking the firms of Pakistan. They found that there is no significant change occurs in the indicators of accounting and financial performance under the process of privatization. Thus, they confirmed that the process of privatization has never enhanced the firm's financial performance in Pakistan.

Hussain (2014) analysed the privatization impact by taking Pakistan's state-owned corporations. The results of this study illustrate that there are no significant improvements noted in operating and financial efficiency in post-privatization of state-owned corporations.

Siddiqi (2012) observe privatization effects on the financial performance of the company and its stock's performance. Results suggest that there is the positive significant effect of privatization on the number of trades, volume and average share prices. However, there is not the considerable influence of privatization observed on the stock returns. Analysis of the financial statistics verifies deterioration in the budgetary performance of the company in the post privatization, which is distinguished by net profit margin, earnings per share ratio, operating profit margin, and return on equity.

Kouser et al. (2012) evaluate and examine the operating and financial performance of those firms that privatize in 1999 to 2005. Overall analysis shows that there is a significant increase in postprivatization performance that is noted in an automobile, fertilizer, cement, financial, energy, and engineering sector. However, chemical and ghee sectors didn't behave well in all measurement indicators. Empirical evidence indicates that efficiency, employment, dividends, investment and profitability rise in post-privatization. But, employment and output decline in financial, but the rise in cement and automobile sector.

Bdour et al. (2007) investigate the potential effect of privatization on operating and financial performance in Jordanian Cement Factories Company (JCFC). The results of the study revealed that operating performance and profit of JCFC didn't extremely affect by privatization. Therefore, it leads to improved liquidity, improved investment, declined in overstaffing and debt reduction. Osman (2000) explored variations in the activities and financial performances of the twenty-four cement factories in the time of pre-privatization. He described statistically significant fluctuations in the net period profits, as well as in the capacity utilization ratios. Moreover, partially significant fluctuations in production levels as well as in investments under the pre and post-privatization time periods. Further, he stated a statistically significant decline in the total number of employees, as well as, the rise in levels of productivity.

Perevalov et al., (2000) present empirical evidence regarding the privatization effect on performance. The results show that, overall, performance improved in the operating profit margin that produces by the privatization, and somewhat, in the labour productivity.

Ochieng and Ahmed (2014) examined the pre and post privatization effects on financial performance in Kenya Aviation industry. Results of this study revealed that there are positive improvements in terms of debt ratios and liquidity ratio in the performance level of Kenya Airways, as compared to pre- 
privatization. Also, performance indicator leads to increase the financial efficiency. Findings indicate that financial efficiency and profitability rise in post-privatization, also solvency level improved, but employment level goes down. Thus, to a greater extent, privatization brings a positive effect on the financial performance of Kenya aviation industry. In other words, privatization enhances the performance level of privatized businesses in terms of financial efficiency and profitability. Boubakri et al. (2004) inspect the performance of recently privatized firms under the post-privatization time period in Asia. Moreover, they also examine the changes in the private ownership structure over the time. Results show that due to privatization, efficiency, output and profitability significantly increases but employment level insignificantly increases in former Asian state-owned firms.

Barghandan (2014) analysed the impact of pre and post-privatization than ownership shifting. The outcome observed on the financial performance, as well as, on the number of investment returns. The outcomes of the study demonstrate that positive effects of privatization on both amounts of investment and financial performance. Thus, privatization prompts firm's profitability.

Tsamenyi a (2010) investigate the two large privatized organization's performance in Ghana. The performances of the organizations are inspected from five primary points of view- customers, financial, community, learning and growth, and the internal business process. The result demonstrates that both organizations have enhanced their performance in post-privatization which demonstrates that privatization causes Ghana to thrive.

Wang (2011) has investigated that what kind of impact privatization leave on the performance of the firm. The investigation is directed for Chinese scenario, moreover, 127 listed companies selected as a sample of this analysis. The outcomes imply that exchange of ownership from government to private area upgrade the financial performance and operational efficiency of the organization that is obvious that there is the positive impact of privatization on the performance of firms.

Yogesh (2012) has looked at the privatized power sector where he compares the two economies i.e. India and Argentina. The outcome demonstrates that distinction in reform has a diverse impact on the productivity and efficiency of the entity in power sector of various nations.

The target of the Sakr's (2014) study is to assess the Egyptian privatization program in terms of performance of firms. He empirically examined whether the privatized firms' operating efficiency enhances the privatization. The results of this investigation show that there is a significantly huge increment in indicators of the operating efficiency, moreover, employment level decreases significantly in the observed firms.

The motivation behind the study of Astami et al. (2010) is to explore performance level of partially privatized state-owned-enterprises (SOEs), to check whether its performance is significantly better as compared to fully privatized State-Owned Enterprises in the underdeveloped nation of Indonesia. Statistical investigation favours the hypothesis that State-Owned Enterprises under the ownership of private sector have a greater level of performance as compared to those completely possessed by the government. Additionally, there are noteworthy significant differences in industry variances, assetsin-place, financial leverage, financial statement reliability, and firm size between completely and partially privatized State-Owned Enterprises. These results favour the Government of Indonesian move towards more privatization in that State-Owned enterprise with some ownership of private sector have more noteworthy performance levels.

There are a number of research studies done in Pakistan on the impact of "Privatization". However, most of the studies discussed pre and post-privatization effects on the banking sector. There is a small number of studies which emphasize on the effects of the privatization on the companies or enterprises. 
These studies focus on the case studies or did a partial analysis of the one or less numb of industries by taking the limited number of parameters. The goal is to remove the space of preceding studies and emphasis on the impact of "Privatization" under the area of financial profitability and efficiency. For the sake of this purpose, investigated the impact of privatization on operating efficiency, liquidity, profitability, leverage and dividends payout. Moreover, in this study selected 06 listed companies of State Owned Enterprises, that are fully privatized or at least $20 \%$ "Privatization" in the year 2000 till 2015 which are currently listed on stock exchange.

\section{Research Hypotheses}

$\mathbf{H}_{\mathbf{1}}:$ Privatization has a significant effect on Operating efficiency.

$\mathbf{H}_{2}$ : Privatization has a significant effect on Liquidity.

$\mathbf{H}_{3}$ : Privatization has a significant effect on Profitability.

$\mathbf{H}_{4}$ : Privatization has a significant effect on Leverage.

$\mathbf{H}_{5}$ : Privatization has a significant effect on Dividend payout.

The main intention of doing research is to assess the effects brought by the process of "Privatization" on the financial performances and efficiency levels of state-owned enterprises. To attain this purpose, the investigation addresses the academic aspects of "Privatization" by appraising the perception, methods, impact, along with experiences of the previously done. This study makes an effort to contribute toward the dispute on how the "Privatization" of public enterprises may influence the financial performance and efficiency of the enterprises.

\section{METHODOLOGY}

This is an explanatory study follows quantitative design. The population contain those SOEs which are privatized in 2004 and others are in 2005. The target population comprises six SOEs i.e. Cement Sector including Kohat Cement Company and Dandot Cement Company, Oil and Gas sector including Pakistan Petroleum Limited (PPL) and National Refinery Limited (NRL), and Service Sector including Pakistan Telecommunication Limited (PTCL) and Karachi Electric Supply Company (KESC).

The data collected for the Kohat Cement industry, Dandot Cement industry, and Pakistan Petroleum Limited (PPL) from 1999 to 2009. These companies are privatized in the year 2004. Moreover, data on National Refinery Limited (NRL), Pakistan Telecommunication Limited (PTCL), and Karachi Electric Supply Company (KESC) collected from the year 2000 to 2010. These companies are privatized in the year of 2005 .

Table 1. Privatization of Companies

\begin{tabular}{|l|l|c|}
\hline Years & \multicolumn{1}{|c|}{ Companies } & Year of Privatization \\
\hline $1999-2009$ & Kohat Cement industry & 2004 \\
\hline $1999-2009$ & Dandot Cement industry & 2004 \\
\hline $1999-2009$ & Pakistan Petroleum Limited (PPL) & 2004 \\
\hline $2000-2010$ & National Refinery Limited(NRL) & 2005 \\
\hline $2000-2010$ & Pakistan Telecommunication Limited(PTCL) & 2005 \\
\hline $2000-2010$ & Karachi Electric Supply Company(KESC) & 2005 \\
\hline
\end{tabular}

Sources: State Bank Library of Pakistan; Official website of the selected companies; Security \& Exchange Commission of Pakistan; Karachi Stock Exchange

In this research, convenience sampling technique is applied that is a particular form of nonprobability sampling technique. It depends on the data gathering from a population which are 
conveniently available for the contribution to the study. Moreover, due to this technique, the process of selecting a sample for the research purpose or analysis is based on the ease and accessibility. Using secondary data of 06 listed companies in Karachi stock exchange that were governed by Government of Pakistan but had been privatized in the different time period. These companies privatized in last 15 years, minimum $20 \%$ privatized state-owned enterprises. Here, data is taken for 10 years for each selected company of this research. From 1999 to 2009, data is available for Kohat cement industry, Dandot cement industry and Pakistan Petroleum Limited, as well as, from 2000 to 2010, data is available for National Refinery Limited, Pakistan Telecommunication Limited, and Karachi Electric Supply Company, only these companies were fully privatized during these years, moreover, the data is available in complete form in case of pre and post-privatization period. Other than these companies, data is not available in complete form for before and after the period of privatization. So, each selected company of this research have 10 years' data, comprising five years before privatization and five years after privatization.

\section{Variables Description}

To check the impact of "Privatization" it has been considered the "Pre \& Post "Privatization" and other variables are "Operating Efficiency, Profitability, Liquidity, Leverage and Dividends payout. Literature also shows that many authors used these kinds of proxies for estimation such as Oqdeh and Nassar (2011), Kousar et al. (2011) and Ocihieng and Ahmed (2014). The indicators which are used for our independent variables are given below in the table.

Table 2: Variables Construction

\begin{tabular}{|l|lll|}
\hline Categories & Indicators & & \\
\hline Profitability & Net Profit Margin= Net Profit/Net Sales & & \\
\hline Liquidity & Current $\quad$ Ratio $=\quad$ Current Current Liabilities \\
\hline Operating Efficiency & Total Asset Turnover=Revenue/Average total assets & \\
\hline Leverage & Total Debt-to-equity ratio= Liabilities/Equity & \\
\hline Dividends Payout & Dividends Pay out =Dividends paid /no. of shares outstanding & \\
\hline
\end{tabular}

\section{RESULTS}

The study compares the pre-and-post privatization performance measures using the empirical proxies of performance that are discussed above broadly in the variable description section. By using the paired sample t-test, compare the performance measures of pre and post-privatization via empirical proxies. Firstly, computed the empirical proxies for both companies over the period of privatization, that means five years pre privatization and five years' post-privatization, moreover, year of privatization excluded (year 0 ) because this year include both public and private phases of ownership.

Before applying paired t-test, the normality of data checked either, it is normally distributed or not. Because, forgetting valid differences, data should be approximately normally distributed. Otherwise, it will not be an appropriate method for data analysis due to extreme outliers. A paired t-test will be used for comparing two means of the population where two samples are required. These samples contain the observations which are paired with each other. It can be before and after observations of the same subjects. For instance, before and after scores of student's diagnostic test for a particular module. Moreover, it can be a comparison of two different methods of measurement or treatments by applying on the same subjects.

Generally, under paired t-test, test the null hypothesis having zero as the true mean difference. For this purpose, firstly calculate differences between pairs and estimate mean difference. Furthermore, calculate standard errors of the mean differences and compute t-statistics. Under the null hypothesis, 
the statistics follow t-distribution having the $\mathrm{n}-1$ degree of freedom. After comparing values of $\mathrm{t}$ distribution in the table for $\mathrm{tn}-1$ distribution, it will provide you P-values for paired t-test. In this research, SPSS used for estimating paired t-test, where simply calculate the differences and then apply the one-sample t-test for getting output.

\section{Cement Sector}

In cement sector, it has been considered two cement companies i.e. Kohat Cement and Dandot Cement. These companies were privatized in the years of 1992 and 1995 respectively. Moreover, they are further 10 percent more privatized in October 2004. For analys ing cement sector, data is collected from 1999 to 2009 for both companies.

\begin{tabular}{|c|c|c|c|c|c|c|c|c|c|}
\hline \multicolumn{10}{|c|}{ Paired Samples Test } \\
\hline & & \multicolumn{5}{|c|}{ Paired Differences } & \multirow[b]{3}{*}{$t$} & \multirow[b]{3}{*}{$d f$} & \multirow[b]{3}{*}{ Sig. (2-tailed) } \\
\hline & & \multirow[b]{2}{*}{ Mean } & \multirow[b]{2}{*}{ Std. Deviation } & \multirow{2}{*}{$\begin{array}{l}\text { Std. Error } \\
\text { Mean }\end{array}$} & \multicolumn{2}{|c|}{$\begin{array}{l}\text { 95\% Confidence Interval of the } \\
\text { Difference }\end{array}$} & & & \\
\hline & & & & & Lower & Upper & & & \\
\hline Pair 1 & $\begin{array}{l}\text { K.C-Pre Operating } \\
\text { Efficiency - KC-Post } \\
\text { Operating Efficiency }\end{array}$ & -.65600 & .81935 & .36642 & -1.67335 & .36135 & -1.790 & 4 & .148 \\
\hline Pair 2 & $\begin{array}{l}\text { K.C-Pre Liquidity - K.C- } \\
\text { Post Liquidity }\end{array}$ & -.25400 & .34674 & .15507 & -.68454 & .17654 & -1.638 & 4 & .177 \\
\hline Pair 3 & $\begin{array}{l}\text { K.C-Pre Profitability - K.C- } \\
\text { Post Profitability }\end{array}$ & -.26400 & .72669 & .32499 & -1.16631 & .63831 & -.812 & 4 & .462 \\
\hline Pair 4 & $\begin{array}{l}\text { K.C-Pre Leverage - K.C- } \\
\text { Post Leverage }\end{array}$ & -.52200 & .41221 & .18435 & -1.03383 & -.01017 & -2.832 & 4 & .047 \\
\hline Pair 5 & $\begin{array}{l}\text { K.C-Pre Dir Payout - K.C- } \\
\text { Post Div Payout }\end{array}$ & 2.35200 & .82120 & .36725 & 1.33235 & 3.37165 & 6.404 & 4 & .003 \\
\hline Pair 6 & $\begin{array}{l}\text { D.C-Pre Operating } \\
\text { Efficiency- D.C-Post } \\
\text { Operating Efficiency }\end{array}$ & -.91400 & .90013 & .40255 & -2.03166 & .20366 & -2.271 & 4 & .086 \\
\hline Pair 7 & $\begin{array}{l}\text { D.C-Pre Liquidity - D.C- } \\
\text { Post Liquidity }\end{array}$ & .69800 & .29634 & .13253 & .33004 & 1.06596 & 5.267 & 4 & .006 \\
\hline Pair 8 & $\begin{array}{l}\text { D.C-Pre Profitability - D. } \\
\text { C-Post Profitability }\end{array}$ & .209400 & 2.851254 & 1.275119 & -3.330899 & 3.749699 & .164 & 4 & .878 \\
\hline Pair 9 & $\begin{array}{l}\text { D.C-Pre Leverage - D.C- } \\
\text { Post Leverage }\end{array}$ & .02800 & 1.63139 & .72958 & -1.99763 & 2.05363 & .038 & 4 & .971 \\
\hline
\end{tabular}

Table 3 Cement Sector

Above table shows the mean values of all variables including Operating efficiency, liquidity, profitability, leverage, and dividends payout pre and post-privatization, by taking Kohat Cement (K.C) and Dandot Cement (D.C) companies.

Kohat cement (K.C) company's results from Pair 1 to Pair 5 clearly illustrated that there is no statistically significant difference between pre and post-privatization and therefore, privatization has not improved the financial performance of the company in terms of operating efficiency, liquidity and profitability. Thus, privatization has an insignificant but negative impact on all these three variables. Moreover, the p-values of leverage and dividends payout shows statistically significant difference between pre and post-privatization and it enhances the financial performance of the company in terms of Leverage and Dividends payout. Thus, privatization has a significant and positive impact on both leverage and dividends payout variables.

Next, results of Dandot Cement (D.C) Company from Pair 6 to Pair 9 show that privatization has a negative but insignificant impact on operating efficiency, profitability and leverage. Thus, there is no statistically significant difference between pre and post-privatization for all these variables, moreover, the financial performance of these variables are going down. However, Liquidity shows positive and significant effects. Hence, it has the statically significant difference between pre and postprivatization which leads substantial impact and enhanced financial performance in terms of Liquidity variable. 


\section{Operating Efficiency}

HA: Privatization has a significant effect on Operating efficiency.

The p-value of operating efficiency for Kohat Cement Company is 0.148 that is greater than the 0.05 level of significance. It shows weak evidence contrary to the null hypothesis of this research; hence, it fails to reject the null hypothesis. The p-value of operating efficiency for Dandot Cement Company is 0.086 that is greater than the 0.05 level of significance. It shows weak evidence contrary to the null hypothesis of this research; hence, it fails to reject the null hypothesis.

\section{- $\quad$ Liquidity}

HA: Privatization has a significant effect on Liquidity.

The p-value of liquidity for Kohat Cement Company is 0.177 that is greater than the 0.05 level of significance. It shows weak evidence contrary to the null hypothesis of this research; hence, it fails to reject the null hypothesis. The p-value of liquidity for Dandot Cement Company is 0.006 that is less than the 0.05 level of significance. It shows strong evidence contrary to the null hypothesis of this research, hence, it rejects the null hypothesis.

\section{- Profitability}

HA: Privatization has a significant effect on Profitability.

The p-value of profitability for Kohat Cement Company is 0.462 that is greater than the 0.05 level of significance. It shows weak evidence contrary to the null hypothesis of this research; hence, it fails to reject the null hypothesis. The p-value of profitability for Dandot Cement Company is 0.878 that is greater than the 0.05 level of significance. It shows weak evidence contrary to the null hypothesis of this research; hence, it fails to reject the null hypothesis.

\section{- Leverage}

HA: Privatization has a significant effect on Leverage.

The p- value of leverage for Kohat Cement Company is 0.047 that is less than the 0.05 level of significance. It shows strong evidence contrary to the null hypothesis of this research, hence, it rejects the null hypothesis. The p-value of leverage for Dandot Cement Company is 0.971 that is greater than the 0.05 level of significance. It shows weak evidence contrary to the null hypothesis of this research, hence, it fails to reject the null hypothesis.

\section{- $\quad$ Dividend Payout}

HA: Privatization has a significant effect on Dividend payout.

The p-value of dividends payout for Kohat Cement Company is 0.003 that is less than the 0.05 level of significance. It shows strong evidence contrary to the null hypothesis of this research; hence, it rejects the null hypothesis.

\section{Oil and Gas Sector}

In this research, Pakistan Petroleum Limited (PPL) and National Refinery Limited (NRL) are considered for the Oil and Gas Sector. Pakistan Petroleum Limited was privatized in 2004, and, National Refinery Limited was privatized in 2005. For analysing the oil and gas sector, data is collected from 1999 to 2009 for PPL and from 2000 to 2010 for NRL. The results of both companies are given below in the table. 


\begin{tabular}{|c|c|c|c|c|c|c|c|c|c|}
\hline \multicolumn{10}{|c|}{ ed Samples } \\
\hline & & \multicolumn{5}{|c|}{ Paired Difarences } & \multirow[b]{3}{*}{$t$} & \multirow[b]{3}{*}{ at } & \multirow[b]{3}{*}{ Sig qataled } \\
\hline & & \multirow[b]{2}{*}{ Mean } & \multirow[b]{2}{*}{ std Deviation } & \multirow{2}{*}{$\begin{array}{l}\text { SAd Error } \\
\text { Wean }\end{array}$} & \multicolumn{2}{|c|}{$\begin{array}{l}\text { 95\% Configence interval of the } \\
\text { Dafotente }\end{array}$} & & & \\
\hline & & & & & Lower & Upeer & & & \\
\hline Pain 1 & 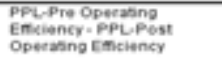 & .46400 & 57208 & 25584 & .24634 & 1.17434 & 1.814 & 4 & .144 \\
\hline Paie 2 & $\begin{array}{l}\text { PPL-Pre Lavion - PPU } \\
\text { Post Liquidey }\end{array}$ & -62600 & 20501 & 09168 & -95056 & -44144 & $-7,591$ & 4 & .002 \\
\hline Paie 3 & $\begin{array}{l}\text { PPL Pre Promabeaty : } \\
\text { PPL-Post Pechtability }\end{array}$ & $-\$ \$ 000$ & An954 & 21093 & -9.46704 & -.25216 & -0.920 & 4 & 017 \\
\hline Pais 4 & $\begin{array}{l}\text { PPL Pre Leverage - PPL. } \\
\text { Post Leverape }\end{array}$ & -92000 & .28073 & 13270 & -1.20044 & -55156 & -6.933 & 4 & .002 \\
\hline Pain 5 & $\begin{array}{l}\text { PPLPre Din Parona : } \\
\text { PPL-Post Div Payout }\end{array}$ & -1.05000 & 79020 & 35700 & -204119 & -05001 & -2.941 & 4 & 042 \\
\hline Paie 6 & $\begin{array}{l}\text { NFeL-Pre Operasng } \\
\text { Criciency- BaAL-Post } \\
\text { Operasno Emciency }\end{array}$ & 41400 & 13221 & 05913 & 24904 & .57016 & 7.002 & 4 & .002 \\
\hline Pain 7 & $\begin{array}{l}\text { NRLL-Pre Laquidity - NRL- } \\
\text { Post Lievides }\end{array}$ & .25200 & .05993 & .92653 & .32567 &., $17 * 93$ & -9.468 & 4 & .001 \\
\hline Pair 8 & $\begin{array}{l}\text { NRL-Pre Prefnabenty - } \\
\text { NFL Post Puctabilly }\end{array}$ & $-2 \$ 800$ & 71142 & 31816 & -1.17135 & .50595 & -.905 & 4 & 417 \\
\hline Pain 9 & $\begin{array}{l}\text { NRLL-Pre Leverage - } \\
\text { NRLL-Post Leverage }\end{array}$ & 72800 & .25513 & 15882 & .28704 & 1.16636 & 4.584 & 4 & .010 \\
\hline Pain 10 & $\begin{array}{l}\text { NRLL-Pre Div Payout - } \\
\text { NRLL-Post Dir Parout }\end{array}$ & 34400 & 38714 & .17314 & $=11670$ & .84470 & 2.102 & 4 & .103 \\
\hline
\end{tabular}

Table 4.: Oil \& Gas Sector

Firstly, describing the results of Pakistan Petroleum Limited (PPL) from Pair 1 to Pair 5. The p-value shows that there is no statistically significant difference between pre and post-privatization that leads to decline in financial performance in terms of operating efficiency. Thus, privatization has a negative and insignificant impact on operating efficiency of PPL. However, the p-values of liquidity, profitability, leverage and dividends payout clearly illustrated that there is the statistically significant difference between pre and post-privatization. Therefore, it leads to increase in financial performance in terms of liquidity, profitability, leverage and dividends payout. Thus, privatization has a positive and significant impact on all these variables. Next, the table is showing the results National Refinery Limited (NRL) from Pair 6 to Pair 10. The results of the table show that privatization has a significant and positive impact on operating efficiency, liquidity and leverage. It has statically positive and significant difference between pre and post-privatization which leads substantial impact and enhanced level of financial performance in terms of all these variables. However, profitability and dividends payout have insignificant effects, which shows that there is negative and no statistically significant difference between pre and post-privatization for both these variables. Therefore, privatization has not enhanced the level of financial performance in terms of dividends payout and profitability.

\section{Operating Efficiency}

HA: Privatization has a significant effect on Operating efficiency.

The p-value of operating efficiency for PPL is 0.144 that is greater than the 0.05 level of significance. It shows weak evidence contrary to the null hypothesis of this research; hence, it fails to reject the null hypothesis. The p-value of operating efficiency for NRL is 0.002 that is less than the 0.05 level of significance. It shows strong evidence contrary to the null hypothesis of this research; hence, it rejects the null hypothesis.

\section{Liquidity}

HA: Privatization has a significant effect on Liquidity.

The p-value of liquidity for Kohat Cement Company is 0.002 that is less than the 0.05 level of significance. It shows strong evidence contrary to the null hypothesis of this research; hence, it rejects the null hypothesis.

The p-value of liquidity for NRL is 0.001 that is less than the 0.05 level of significance. It shows strong evidence contrary to the null hypothesis of this research, hence, it rejects the null hypothesis. 
Profitability

HA: Privatization has a significant effect on Profitability.

The p-value of profitability for PPL is 0.017 that is less than the 0.05 level of significance. It shows strong evidence contrary to the null hypothesis of this research, hence, it rejects the null hypothesis.

The p-value of profitability for NRL is 0.417 that is greater than the 0.05 level of significance. It shows weak evidence contrary to the null hypothesis of this research, hence, it fails to reject the null hypothesis.

\section{Leverage}

HA: Privatization has a significant effect on Leverage.

The p-value of leverage for PPL is 0.002 that is less than the 0.05 level of significance. It shows strong evidence contrary to the null hypothesis of this research; hence, it rejects the null hypothesis. The pvalue of leverage for NRL is 0.10 that is equal to the 10 percent or 0.10 level of significance. It shows strong evidence contrary to the null hypothesis of this research; hence, it rejects the null hypothesis.

\section{Dividend Payout}

HA: Privatization has a significant effect on Dividend payout.

The p-value of dividends payout for PPL is 0.042 that is less than the 0.05 level of significance. It shows strong evidence contrary to the null hypothesis of this research; hence, it rejects the null hypothesis. The p-value of dividends payout for NRL is 0.103 that is greater than the 0.05 level of significance. It shows weak evidence contrary to the null hypothesis of this research; hence, it fails to reject the null hypothesis.

\section{Service Sector}

For analysing the impact of pre and post-privatization, Pakistan Telecommunication Limited (PTCL) and Karachi Electric Supply Company (KESC) are considered for Service Sector. Pakistan Telecommunication Limited (PTCL) and Karachi Electric Supply Company (KESC) were privatized in 2005. Moreover, data is collected from 2000 to 2010 for both companies. The results of both companies are given below in the table.

\begin{tabular}{|c|c|c|c|c|c|c|c|c|c|}
\hline & & \multicolumn{5}{|c|}{ Paired Diflarences } & \multirow[b]{3}{*}{$t$} & \multirow[b]{3}{*}{ df } & \multirow[b]{3}{*}{$\operatorname{sig}(2-\operatorname{tal} 4)$} \\
\hline & & \multirow[b]{2}{*}{ Mean } & \multirow[b]{2}{*}{ Std. Deviason } & \multirow{2}{*}{$\begin{array}{c}\text { std. Error } \\
\text { Mean }\end{array}$} & \multicolumn{2}{|c|}{$\begin{array}{l}\text { 95\% Confidente interval of the } \\
\text { Diffarence }\end{array}$} & & & \\
\hline & & & & & Lower & Uscar & & & \\
\hline Pair 1 & $\begin{array}{l}\text { PTCL_Pre Operating } \\
\text { Efficiency-PTCL-Pest } \\
\text { Operating Efficiency }\end{array}$ & -.10400 & .08849 & .03957 & .21387 & 00587 & -2628 & 4 & .058 \\
\hline Pair 2 & $\begin{array}{l}\text { PTCL.Pre Liquidity - } \\
\text { PTCL-Post Liquidity }\end{array}$ & .10200 & .45202 & .20215 &. .45925 & .66325 & 505 & 4 & .640 \\
\hline Pair 3 & $\begin{array}{l}\text { PTCL-Pre Peotatadify - } \\
\text { PTCL-Post Proftability }\end{array}$ & 1.30400 & 208085 & 93058 & -1.27971 & 388771 & 1.401 & 4 & .234 \\
\hline Pair 4 & $\begin{array}{l}\text { PTCL.Pre Leverage - } \\
\text { PTCL.Post Leverage }\end{array}$ &,- 15200 & .65511 & .29297 & .96543 & .66143 & .519 & 4 & .631 \\
\hline Pair 5 & $\begin{array}{l}\text { PTCL-Pre DN Paysut - } \\
\text { PTCL-Post Dw Payout }\end{array}$ & .62600 & 204249 & .91343 & .1 .91009 & 3.16209 & -685 & 4 & .531 \\
\hline Pair 6 & $\begin{array}{l}\text { KESC-Pre Operating } \\
\text { Efficiency- KESC-Post } \\
\text { Operating Efficiensy }\end{array}$ & 1.30200 & .12716 & 05687 & 1.14411 & 1.45989 & 22895 & 4 & .000 \\
\hline Pair 7 & $\begin{array}{l}\text { KESC-Pre Liquidity : } \\
\text { KESC-Post Uiquidey }\end{array}$ & .22600 & .53817 & .24068 & -.44223 & .89423 & .999 & 4 & 401 \\
\hline Pair 8 & $\begin{array}{l}\text { KESC.Pre Proftability : } \\
\text { KESC-Post Profabilify }\end{array}$ & -74000 & 4.60036 & 205735 & -6.45211 & 497211 & -360 & 4 & .797 \\
\hline Pair 9 & $\begin{array}{l}\text { KESC-Pre Leverage - } \\
\text { kESC-Postlaverage }\end{array}$ & -2.72200 & 1.91934 & .85836 & -5.10518 & -33982 & -3.171 & 4 & .034 \\
\hline
\end{tabular}

Table 5 Service Sector 
Firstly, showing the results of Pakistan Telecommunication Limited (PTCL) from Pair 1 to Pair 5. The p-values of all variables including operating efficiency, liquidity, profitability, leverage, and dividends payout show the negative and insignificant effects. On the basis of P-values, the results of above table clearly illustrated that there is no statistically significant difference between pre and postprivatization of all variables that leads to decrease in the level of financial performance in terms of operating efficiency, liquidity, profitability, leverage, and dividends payout. Thus, privatization has a negative and insignificant impact on all variables of PTCL. Next, the table is illustrating results of KESC from Pair 6 to Pair 9. The results of the table show that privatization has a significant impact on operating efficiency, as well as, on leverage. Thus, there is statistically positive and significant difference between pre and post-privatization for both these variables. Therefore, privatization improves the level of financial performance in terms of operating efficiency and leverage. However, Liquidity and profitability show insignificant effects. Hence, it has statically negative and insignificant difference between pre and post-privatization that leads no substantial enhancement in the level of financial performance.

\section{Operating Efficiency}

HA: Privatization has a significant effect on Operating efficiency.

The p-value of operating efficiency for PTCL is 0.58 that is greater than the 0.05 level of significance. It shows weak evidence contrary to the null hypothesis of this research, hence, it fails to reject the null hypothesis. The p-value of operating efficiency for KESC is 0.000 that is less than the 0.05 level of significance. It shows strong evidence contrary to the null hypothesis of this research; hence, it rejects the null hypothesis.

\section{Liquidity}

HA: Privatization has a significant effect on Liquidity.

The p-value of liquidity for PTCL is 0.640 that is greater than the 0.05 level of significance. It shows weak evidence contrary to the null hypothesis of this research; hence, it fails to reject the null hypothesis. The p-value of liquidity for KESC is 0.401 that is greater than the 0.05 level of significance. It shows weak evidence contrary to the null hypothesis of this research, hence, it fails to reject the null hypothesis.

\section{Profitability}

HA: Privatization has a significant effect on Profitability.

The p-value of profitability for PTCL is 0.234 that is greater than the 0.05 level of significance. It shows weak evidence contrary to the null hypothesis of this research, hence, it fails to reject the null hypothesis. The p-value of profitability for KESC is 0.737 that is greater than the 0.05 level of significance. It shows weak evidence contrary to the null hypothesis of this research; hence, it fails to reject the null hypothesis.

\section{Leverage}

HA: Privatization has a significant effect on Leverage.

The p-value of leverage for PTCL is 0.631 that is greater than the 0.05 level of significance. It shows weak evidence contrary to the null hypothesis of this research, hence, it fails to reject the null hypothesis. The $p$-value of leverage for KESC is 0.034 that is less than the 0.05 level of significance. It shows strong evidence contrary to the null hypothesis of this research; hence, it rejects the null hypothesis.

Dividend Payout

HA: Privatization has a significant effect on Dividend payout.

The p-value of dividends pay out for PTCL is 0.531 that is greater than the 0.05 level of significance. It 
shows weak evidence contrary to the null hypothesis of this research; hence, it fails to reject the null hypothesis.

\section{DISCUSSION}

In this section, the overall results of this study describe and concluded that how much privatization affects the financial performance and efficiency of selected sectors Pakistan.

Table 5: Impact of the Privatization

\begin{tabular}{|c|c|c|c|c|c|c|}
\hline \multirow[b]{2}{*}{ Variables } & \multicolumn{2}{|c|}{ CEMENTSECTOR } & \multicolumn{2}{|c|}{ OIL AND GAS SECTOR } & \multicolumn{2}{|l|}{ SERVICES SECTOR } \\
\hline & $\begin{array}{l}\text { Kohat } \\
\text { Cement } \\
\text { Company }\end{array}$ & $\begin{array}{l}\text { Dandot } \\
\text { Cement } \\
\text { Company }\end{array}$ & $\begin{array}{l}\text { Pakistan } \\
\text { Petroleum } \\
\text { Limited }\end{array}$ & $\begin{array}{l}\text { National } \\
\text { Refinery } \\
\text { Limited }\end{array}$ & $\begin{array}{l}\text { Pakistan } \\
\text { Telecommunication } \\
\text { Limited }\end{array}$ & $\begin{array}{l}\text { Karachi } \\
\text { Electric }\end{array}$ \\
\hline $\begin{array}{l}\text { Operating } \\
\text { Efficiency }\end{array}$ & Insignificant & Insignificant & Insignificant & Significant & Insignificant & Significant \\
\hline Liquidity & Insignificant & Significant & Significant & Significant & Insignificant & Insignificant \\
\hline Profitability & Insignificant & Insignificant & Significant & Insignificant & Insignificant & Insignificant \\
\hline Leverage & Significant & Insignificant & Significant & Significant & Insignificant & Significant \\
\hline $\begin{array}{l}\text { Dividends } \\
\text { Payout }\end{array}$ & Significant & 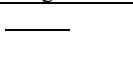 & Significant & Insignificant & Insignificant & \\
\hline
\end{tabular}

The empirical analysis of this research shows that most of the variables of SOEs are insignificantly affected by the privatization in Pakistan other than PPL. Above table illustrated that privatization enhances the financial performance of PPL in terms of liquidity, profitability, leverage and dividends payout. It means the financial performance of the PPL is enhanced as compared to other companies. Because, in other sectors or companies, most of the variables are showing insignificant behaviour toward the privatization periods, and as a result their level of Financial Performance decline.

Operating efficiency showing insignificant performance in all companies except NRL and KESC. Therefore, the impact of the privatization is not significant on operating efficiency, that is similar with the findings of Hakro and Akram (2009), and Hussain (2014). However, Kouser et al. (2012), Oqdeh and Nassar (2011), Boubakri et al. (2004) and Sakr (2014) found a significant impact of privatization on Operating Efficiency.

Moreover, Liquidity has insignificant values for half number of the companies which are considered for this research and significant values for other remaining companies. Kohat cement, PTCL, and KESC are insignificantly affected by the privatization. Therefore, the impact of the privatization on Service Sector and Kohat Cement company is insignificant, whereas, significant impact on Oil and Gas Sector, as well as, on Dandot Cement. Bdour et al. (2007) estimated the significant rise in liquidity for the selected Jordan Cement Factories (JCFC), moreover, Oqdeh and Nassar (2011) observed significant decline in liquidity for selected Jordanian firms. Also, above table demonstrates that Profitability observed insignificant in all companies except PPL. Therefore, privatization has an insignificant impact on Profitability for the selected companies of Pakistan. This result is similar to the findings of the Hakro and Akram (2009), Hussain (2014), and Oqdeh and Nassar (2011). They also found no significant increment in profitability due to privatization. However, Wang (2011), Boubakri et al. (2004), and Kouser et al. (2012) show the significant and positive impact of the privatization on Profitability. Furthermore, Leverage of all companies except Dandot Cement Company and PTCL is significant. It means that impact of the privatization is significant for most of the selected companies of Pakistan. Hussain (2014) and Oqdeh and Nassar (2011) shows insignificant improvements in leverage due to privatization. Moreover, Dividends Payout is significant for Kohat Cement Company and PPL, whereas, insignificant for NRL and PTCL. Dandot Cement Company and KESC have not paid their dividends, that's why their values are not mentioning here. Hakro and Akram (2009) show insignificant, whereas, Kousar et al. (2012) and Oqdeh and Nassar (2011) show a significant rise in dividends parameters. 
At the sectoral level, this research explains that privatization brings changes in some values of variables, whereas, remaining variables are same as they are before privatization period. It means privatization has never enhanced the Cement Sector and Services sector's Financial performance in Pakistan just like the findings of Hakro and Akram (2009). However, previous literature like Hussain (2014) took various sectors including Oil and Gas, Auto, Cement, Chemicals, and Banking and Financial sectors, and observed insignificant improvements in operating and financial efficiency of all sectors. Moreover, Kousar et al. (2012) found a significant increase in the performance of Automobile, Fertilizer, Cement, Financial, Energy and Engineering sector. In this research, privatization enhances the Financial Performance of the Oil and Gas sector in Pakistan. There is a little number of previous studies are available in the service provider sector including PTCL but have not found on KESC. Siddiqi et al. (2012) analyzed PTCL sector and found that privatization has insignificant impact on this sector.

Overall, analysis of this research shows that impact of the privatization is insignificant and level of Financial performance decline in sectors including Cement Sector (Kohat Cement Company and Dandot Cement Company), and Service Sector (PTCL and KESC). However, most of the values of Oil and Gas Sector (PPL and NRL) are signs that show a high level of financial performance of the company. Thus, on the basis of the empirical results, privatization has an insignificant impact on Operating Efficiency, Liquidity, Profitability, Leverage, and Dividends Payout.

\section{CONCLUSION AND RECOMMENDATIONS}

\section{Conclusion}

The study is intended to compare the financial performance and efficiency of state-owned enterprises for (pre-post) privatization procedure in Pakistan. The objective of this study to check the potential impact of the Privatization on Financial Performance and Efficiency levels of selected companies. In order to achieve this objective, a number of empirical proxies including profitability, liquidity, operating efficiency, leverage and dividends payout are utilized to measure the financial performance and efficiency of selected State-Owned Enterprises. Moreover, to examine the impact of privatization on financial performance and efficiency of selected enterprises, the study followed Paired t-test. There are insignificant results are noted for Cement Sector (Kohat and Dandot cement companies) and Service Sectors (PTCL and KESC), whereas, significant results are documented for Oil and Gas sector (PPL and NRL). Thus, no convincing and significant evidence found which recommend a significant change in financial performance and efficiency of Cement and Service Sectors in pre-post privatization process in Pakistan, and vice-versa for Oil and Gas Sector.

\section{Recommendations}

Based on the findings of this research, there is a number of following recommendations present that ought to be kept in mind while thinking about privatization as a solution for the inefficiency of public institutions:

The policy-makers (GOP) must realise that changing ownership structure per se has no instant effect on firm performance, but in time would yield greater rewards when competition replaces in a monopoly in case of KESC and PTCL.

The government of Pakistan should also allow the private sector to compete with their SOEs, which would encourage these SOEs to shift their management-style toward maximizing efficiency and profitability in order to survive.

The study has shown that overall financial performance in the pre and post-privatization era is not significantly different. This should however not put a halt to the privatization process. There is need to look at the valuation of enterprises that are up for privatization, future earning flows and the firm 
gearing ratios are factors that are known to influence the value of IPOs.

\section{REFERENCES}

Abraham, A. (2006). Financial management in the nonprofits sector: A mission based approach to ratio analysis in membership organisations. (S. database, Ed.) The Journal of American Academy of Business, 9(2), 212-217.

Al-Taani, Khalaf. 2013. The Impact of Privatization on Financial Performance of State Owned Enterprises: A Case Study of the Jordanian Cement Factories Company. Journal of Finance and Accounting; 1(3): , 41-45.

Astami, E. W., Tower, G., Rusmin, R., \& Neilson, J. (2010). The effect of privatization on performance of state-owned-enterprises in Indonesia. Asian Review of Accounting, 18(1), 519.

Barghandan, N. D. (2014). Examining the Impact of Privatization on the Companies' Performance and Rate of Return. A Journal of Economics and Management Vol. 3 Issue 10 , 1-13.

Bdour, J. I., Qaqish, M. H., Ta'ani, K. S., \& Refugees, D. P. (2007). The Effect of Privatization on the Efficiency of Financial Performance of State-Owned Enterprises: A Case Study of the Jordanian Cement Factories Company. In 7 th Global Conference on Business \& Economics.

Boubakri, N., Cosset, J. C., \& Guedhami, O. (2004). Privatization, corporate governance and economic environment: Firm-level evidence from Asia. Pacific-Basin Finance Journal, 12(1), 65-90.

Burton, J. (1987). Privatization: The Thatcher Case. Managerial and Decision Economics, 1, 21-29.

Cabanda, E., \& Ariff, M. (2002). Performance gains through privatization and competition of Asian telecommunications. ASEANEconomic Bulletin, 254-279.

Cao, Y., Qian, Y. \& Weingast, B. (1999). From federalism, Chinese style to privatization, Chinese style. Economics of Transition, 7, 103-31.

Delen, D., Kuzey, C., \& Uyar, A. (2013). Measuring firm performance using financial ratios: A decision tree approach. Expert Systems with Applications, 40(10), 3970-3983.

Earle, J. S., \& Telegdy, Á. (2002). Privatization methods and productivity effects in Romanian industrial enterprises. Journal of Comparative Economics, 30(4), 657-682.

Filipovic, A. (2005). Impact of Privatization on Economic Growth. Issues in Political Economy, Vol. 14

Garnaut, Ross, Song, Ligang, Tenev, Stoyan, Yao, Yang, 2003. A Study of Firm Restructuring in China. The World Bank, Washington, DC

Guriev, S., \& Megginson, W. (2007). Privatization: What have we learned? In Annual World Bank Conference on Development Economics-Regional 2007: Beyond Transition (pp. 249-96).

Hakro, A. N. \& Akram, M. (2009). Pre-Post performance assessment of privatization process In Pakistan. International Review of Business Research Papers, Vol.5(1), Pp. 70-86

Hussain, A. (2014). State Owned Enterprises and Private Firms in A Competitive Environment: A Case of Pakistan. City University Research Journal, 4(1).

Karamustafa, O. (2000). An Analysis of Pre-Privatization and Post-Privatization Financial Performance and Activities of Privatized Cement Companies. Istanbul Stock Exchange Review, 4(16), 1-9.

Kouser, R., Azid, T., \& Ali, K. (2011). Emergent Thinking on Privatization: A Review Analysis. Pakistan Journal of Social Sciences (PJSS), 31(1).

Kouser, R., Azid, T., \& Ali, K. (2012). Financial and operating performance of privatized firms: A case study of Pakistan. International Research Journal of Finance and Economics, 87(87), 90116.

Lin, Y. \& Zhu, T. (2001). Ownership restructuring in Chinese state industry: An analysis of evidence on initial organizational changes. China Quarterly, $0(166), 305-41$.

Mathew Tsamenyi a, J. O.-K. (2010). Post-privatization performance and organizational changes: Case studies from Ghana. Critical Perspectives on Accounting 21, 428-442. 
Megginson, W. L., Nash, R. C., \& Randenborgh, M. (1994). The financial and operating performance of newly privatized firms: An international empirical analysis. The Journal of Finance, $49(2), 403-452$.

Megginson, W.L., \& Netter, J.M. (2001). From State to Market: A Survey of Empirical Studies on Privatization. Journal of Economic Literature, 39, 321-389. Journal of Managerial Sciences Volume VINumber 2, 189-200.

Megginson, W.L., and Netter, J.M. (2001). From State to Market: A Survey of Empirical Studies on Privatization. Journal of Economic Literature, 39, 321-389.

Mintzberg, H. \& Waters, J.A. 1989. Of strategies, deliberate and emergent. In: Asch, D. \& Bowman, C. (eds.) Readings in strategic management, pp. 37-56. Macmillan, London, in association with the Open University.

Muhammad Fahad Siddiqi, M. N. (2012). Does Privatization Affect Performance?

Muthini, L. M. The effect of privatization on financial performance of state owned enterprises (A Case Study of Formerly State-owned Enterprises Listed at Nairobi Stock Exchange) (Doctoral dissertation).

Nellis, J. (1991). Improving the Performance of Soviet Enterprises. World Bank Discussion Paper No. 118

Ochieng, M. D., \& Ahmed, A. H. (2014). The effects of privatization on financial performance of Kenya Airways. International Journal of Business and Commerce, 3(5), 10-26.

Oliveros, P. A. (2012). The efficiency of state-owned and privatized firms: Does ownership make a difference? International Journal of Production Economics Volume 140, Issue 1, , 457-465

Omran, Mohammad. (2004). The Performance of State Owned Enterprises and Newly Privatised Firms: Empirical Evidence from Egypt. The Arab Academy of Science and Technology and Arab Monetary Fund.

Oqdeh, L. N., \& Abu Nassar, M. (2011). Effects of Privatization on Firms Financial and Operating Performance: Evidence from Jordan. Dirasat: Administrative Sciences, 161(717), 1-32.

Oyieke, S. 2002. Kenya Airways: A Case Study of Privatization. AERC Research Paper No. 119. African Economic Research Consortium, Nairobi, Kenya.

Pandian, M., and Narendran, M (2015). Impact of financial performance indicators of profitability. International journal of currenr research, 7(1), 12141-12149

Perevalov, Y., Gimadi, I., and Dobrodey, V. (2000). The Impact of Privatization on the Performance of Medium and Large Industrial Enterprises. Economic Education and Research Consortium Working Paper, 2K-01.

Qian Sun, Wilson H. S. Tong and Ding Tong. (2002). How Does Government Ownership Affect Firm Performance? Evidence from China's Privatization Experience. Journal of Business Finance \& Accounting, 29(1) \& (2), 0306-686X.

Quiggin, J.2002, 'Privatisation and nationalisation in the 21st century', Growth, no. 50, pp. 66-73.

Sakr, A. (2014). The Impact of Privatisation on the Performance of Firms in Egypt. Research Journal of Finance and Accounting, 5(15), 73-81.

Shahdeh, K.S. (2002). Lessons from Privatization in Arab Countries. Development Information Unit for Arab Countries, UNDP, 10-11.

Starr, P. (1988). The Meaning of Privatization. Yale Law and Policy Review, 6, 6-41.

Vintila, G., \& Nenu, E. A. (2015). An Analysis of determinants of corporate financial performance: Evidence from the bucharest stock exchange listed companies. International Journal of Economics and Financial Issues, 5(3).

Wang, Z. H. (2011). Ultimate privatization and change in firm performance: Evidence from China. China Economic Review Volume 22, Issue 1, 121-132.

Yergin, D., \& Stanislaw, J. (1998). The Commanding Heights: The Battle between Government and the Marketplace That Is Remaking the Modern World. NY: Simon \& Schuster.

Yogesh, M. G. (2012). Privatization in power sector: A comparative study of India \& Argentina. International Journal of Multidisciplinary Management Studies Volume: 2, Issue: 9, 268280. 
IBT Journal of Business Studies

Young, P. (1987). Privatization around the world. Proceedings of the Academy of Political Science, 36(3), 190-206. 